\title{
OXINITROCARBURIZING IN FLUIDIZED BED TECHNOLOGY APPLIED TO DRAWING STEELS
}

\author{
Nelu CAZACU \\ "Dunarea de Jos" University of Galati, Faculty of Engineering \\ e-mail: nelu.cazacu@ugal.ro
}

\begin{abstract}
Steels oxinitrocarburizing is a thermochemical treatment in order to obtain a slight increase of mechanical properties associated with increased of corrosion resistance. The paper is based on experiments performed on a plant with fluidized bed. Environment for oxinitrocarburizing is achieved by means of fluidized solid granules sorted by size ranging within 0.10-0.16 mm, resulting from decomposing a gas mixture of methane and ammoniac (initially). Samples are used in low carbon steels. Controlled oxidation is performed at a temperature of $570{ }^{\circ} \mathrm{C}$ with superheated water vapor. The results confirm the possibility to obtain layer structure and to increase surface mechanical properties.
\end{abstract}

KEYWORDS: fluidized bed, oxinitrocarburizing, drawing steel

\section{Introduction}

Oxinitrocarburizing (ONC) treatment is a relatively new, dedicated parts being obtained by cold plastic deformation of steel or other materials. Oxinitrocarburizing is a thermochemical treatment of low carbon steels and from which we obtain an increase in surface properties and corrosion resistance. The principle of treatment is close to the ferritic nitriding (FN) treatment, considered low-cost option. Treatment environment is usually gas or plasma, for which we obtain the lowest costs [1,2].

In [3] oxinitrocarburizing (ONC) is considered a complex heat treatment with three stages (Triplex): CVD + Diffusion + oxidation

Complex treatment of ferric nitrocarburizing (FNC) under different conditions and then followed by oxidation is shown in [4]. FNC is studied at various temperatures ranging from $630{ }^{\circ} \mathrm{C}$ to $570{ }^{\circ} \mathrm{C}$ and post-oxidation is performed at $550{ }^{\circ} \mathrm{C}$.

A completed treatment of nitrocarburizing using plasma and gas environment C60W on steel samples at a temperature of $570{ }^{\circ} \mathrm{C}$ while maintaining a 4 hour and 8 hours is shown in [5].

Fluidized bed as a medium for oxinitrocarburizing has some features that are found in the advantages and disadvantages as a medium for heating: bottom up;
- has a very high thermal conductivity at correct fluid flow;

- heat transfer coefficient has high values;

- mass transfer coefficient has high values;

- the pieces (samples) are set in the middle of the fluidized bed;

- there is a central movement upward, specify for wall descent of fluidized bed;

- there is an active area immediately after the fluidisation plaque (grille);

- assets are slightly sloping surfaces;

- horizontal surfaces are considered dead.

It can be noted that the fluidized layer has limitations for the fixed bed and the pneumatic transport (Fig. 1).

The properties of the fluidized bed vary with temperature and fluidization velocity. Therefore, the establishment of the quiet fluidization field leads to the optimization of the thermal and mass transfer properties and is a prerequisite for the achievement of the established processes. Depending on the speed of fluidization, the following areas are established:

- $0 \ldots \mathrm{W}_{\mathrm{cr}}$, fixed bed;

- $\mathrm{W}_{\mathrm{cr}} \ldots \mathrm{W}_{\mathrm{f}}^{\prime}$, beginning of fluidization;

- $W_{f}^{\prime} \ldots W_{f}^{\prime}$, the field of fluidization;

- $\mathrm{W}_{\mathrm{f}} \mathrm{f}_{\mathrm{f}} . \mathrm{W}_{\mathrm{pl}}$, field of turbulent fluidization;

- $\quad \mathrm{W}>\mathrm{W}_{\mathrm{pl}}$, pneumatic transport.

Due to operating principles can be inferred that using fluidized bed can be opportune for thermal and thermochemical treatments. Altering the chemical composition of the nitriding gas: carburizing, nitriding, hardening, nitrocarburizing can be obtained. 


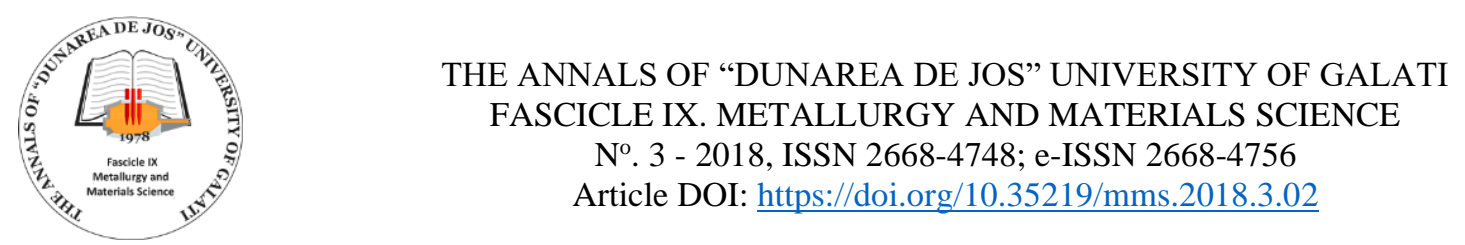

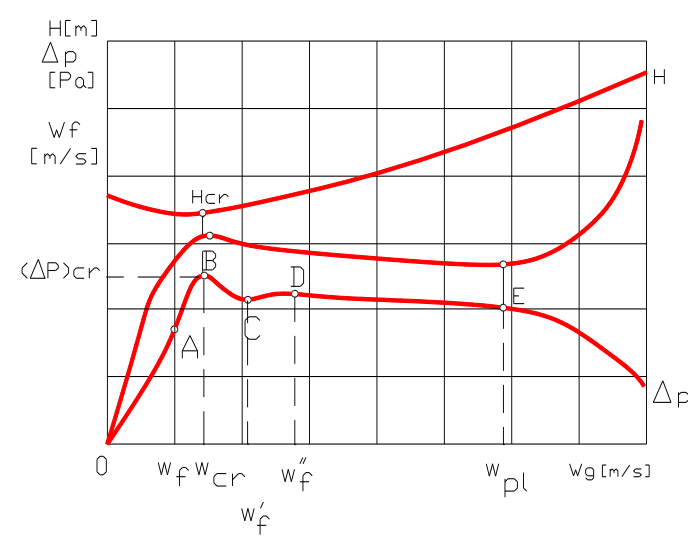

Fig. 1. Dependency of height (H), speed of filtration and fluidization $\left(w_{f}\right)$, and drop pressure $\left(\Delta_{p}\right)$, of gas velocity $\left(w_{g}\right)[6-8]$

\section{Notation and abbreviations:}

$\mathrm{w}_{\mathrm{f}}$ - fluidization speed, $\mathrm{m} / \mathrm{s}$

$\Delta_{\mathrm{p}}$ - drop pressure, mbar

CVD - Chemical Vapour Deposition

ONC - OxiNitroCarburizing

$\mathrm{CN}$ - CarboNitriding

FNC - Ferrite Nitrocarburizing

FN - Ferritic Nitriding

$\mathrm{O}$ - Oxidation

$\mathrm{W}_{\mathrm{cr}}$ - critical fluidization speed

$\mathrm{W}_{\mathrm{f} 0}^{\prime}$ - minimum fluidization speed

$\mathrm{W}_{\mathrm{pl}}$ - floating speed

W's - optimal fluidization speed

$\mathrm{W}_{\mathrm{pl}}$ - floating speed

The use of the fluidized bed in thermal and thermo-chemical treatments also has the advantage of being able to make diverse inlet gas mixtures by controlling the pressure and flow of each component. This is because the experimental plant is open and after the fluidized bed is evacuated, the combustion gases are completely burnt. For oxinitrocarburizing experiments in fluidized bed were used mixture of different gasses - methane, ammonia and air. After reaction in the exhaust air fluidized there are methane (butane, propane) ammoniac, hydrogen, nitrogen, except that the last ones are combustible and form water vapor and $\mathrm{CO}_{2}$.

\section{Experimental}

The thermochemical treatment was performed on the fluidized bed installation of Engineering Faculty of "Dunarea de Jos" University of Galati (Fig. 2).

Installation elements are: 1 - power supply system and temperature control, 2 - fluidized bed oven, 3 - rack gas supply technological, 4 - hood to evacuate fumes [9-12].
Thermochemical treatment plant usually shows a fluidized bed evaporator posted to the gas supply to prevent water vapour oxidizing atmosphere [12, 13]. In experimental superheated water, vapour atmosphere is obtained by introducing water directly into the start of fluid found at $570{ }^{\circ} \mathrm{C}$, with a vent pipe at the fluidized bed base, a transition regime was performed to change fluidizations on hated water vapour.

The research was based on those steel sheets prepared and rolled into industrial plant. These samples were subjected to thermochemical treatments in order to apply and obtain parts with improved wear properties and oxidation related to the automotive industry. For testing were used samples of steel with chemical composition shown in Table 1 (after annealing treatment). After surface cleaning and polishing, samples were introduced into the furnace in vertical and central position so that there will be two areas covered by oxinitrocarburizing.

Table 1. Experimental regimes $(\mathrm{NC}+\mathrm{O})$

\begin{tabular}{|c|c|c|c|c|}
\hline \multirow[b]{2}{*}{ Exp. } & \multicolumn{2}{|c|}{ NitroCarburizing (NC) } & \multicolumn{2}{|c|}{ Oxidizing (O) } \\
\hline & $\begin{array}{l}\text { Tempe- } \\
\text { rature }\end{array}$ & Time & $\begin{array}{l}\text { Tempe- } \\
\text { rature }\end{array}$ & Time \\
\hline u.m. & ${ }^{\circ} \mathrm{C}$ & $\min$ & ${ }^{\circ} \mathrm{C}$ & $\min$ \\
\hline 1 & \multirow{4}{*}{$\mathrm{NC} 650^{\circ} \mathrm{C}$} & 60 & \multirow{16}{*}{570} & \multirow{16}{*}{120} \\
\hline 2 & & 80 & & \\
\hline 3 & & 100 & & \\
\hline 4 & & 120 & & \\
\hline 5 & \multirow{4}{*}{$\begin{array}{c}\mathrm{NC} 650^{\circ}-> \\
570^{\circ} \mathrm{C}\end{array}$} & 60 & & \\
\hline 6 & & 80 & & \\
\hline 7 & & 100 & & \\
\hline 8 & & 120 & & \\
\hline 9 & \multirow{4}{*}{$\mathrm{NC} 570^{\circ} \mathrm{C}$} & 60 & & \\
\hline 10 & & 80 & & \\
\hline 11 & & 100 & & \\
\hline 12 & & 120 & & \\
\hline 13 & \multirow{4}{*}{$\mathrm{NC} 540^{\circ} \mathrm{C}$} & 60 & & \\
\hline 14 & & 80 & & \\
\hline 15 & & 100 & & \\
\hline 16 & & 120 & & \\
\hline
\end{tabular}

Oxinitrocarburizing fluidized bed is mainly located after a continuous cycle known as thermochemical treatment because the initial mixture composition change is to modify the composition of the active gas treatments.

Table 1 shows the conditions for achieving oxinitrocarburizing thermochemical treatment.

The experimental regimes are carried out in the same fluidized bed furnace in two successive stages, 
for which, besides the fluidization parameters, are regulated the temperature of the regime, the chemical composition of the incoming gases, the water pressure at the vaporizer inlet.

Table 2. Chemical composition for samples

\begin{tabular}{|c|c|c|c|c|c|c|c|c|c|c|c|c|c|c|c|c|c|}
\hline $\mathrm{C}$ & $\mathrm{Si}$ & $\mathrm{Mn}$ & $\mathrm{P}$ & $\mathrm{S}$ & $\mathrm{Al}$ & $\mathrm{As}$ & $\mathrm{Ti}$ & $\mathrm{V}$ & $\mathrm{Cu}$ & $\mathrm{Ni}$ & $\mathrm{Cr}$ & $\mathrm{Mo}$ & $\mathrm{Nb}$ & $\mathrm{N} 2$ & $\mathrm{Ca}$ & $\mathrm{Cev}$ & $\mathrm{H} 2$ \\
\hline 0,004 & 0,02 & 0,24 & 0,015 & 0,01 & 0,06 & 0,02 & 0,001 & 0,001 & 0,015 & 0,015 & 0,019 & 0,002 & 0,001 & 0,0065 & 0,0001 & 0,089 & 0 \\
\hline
\end{tabular}
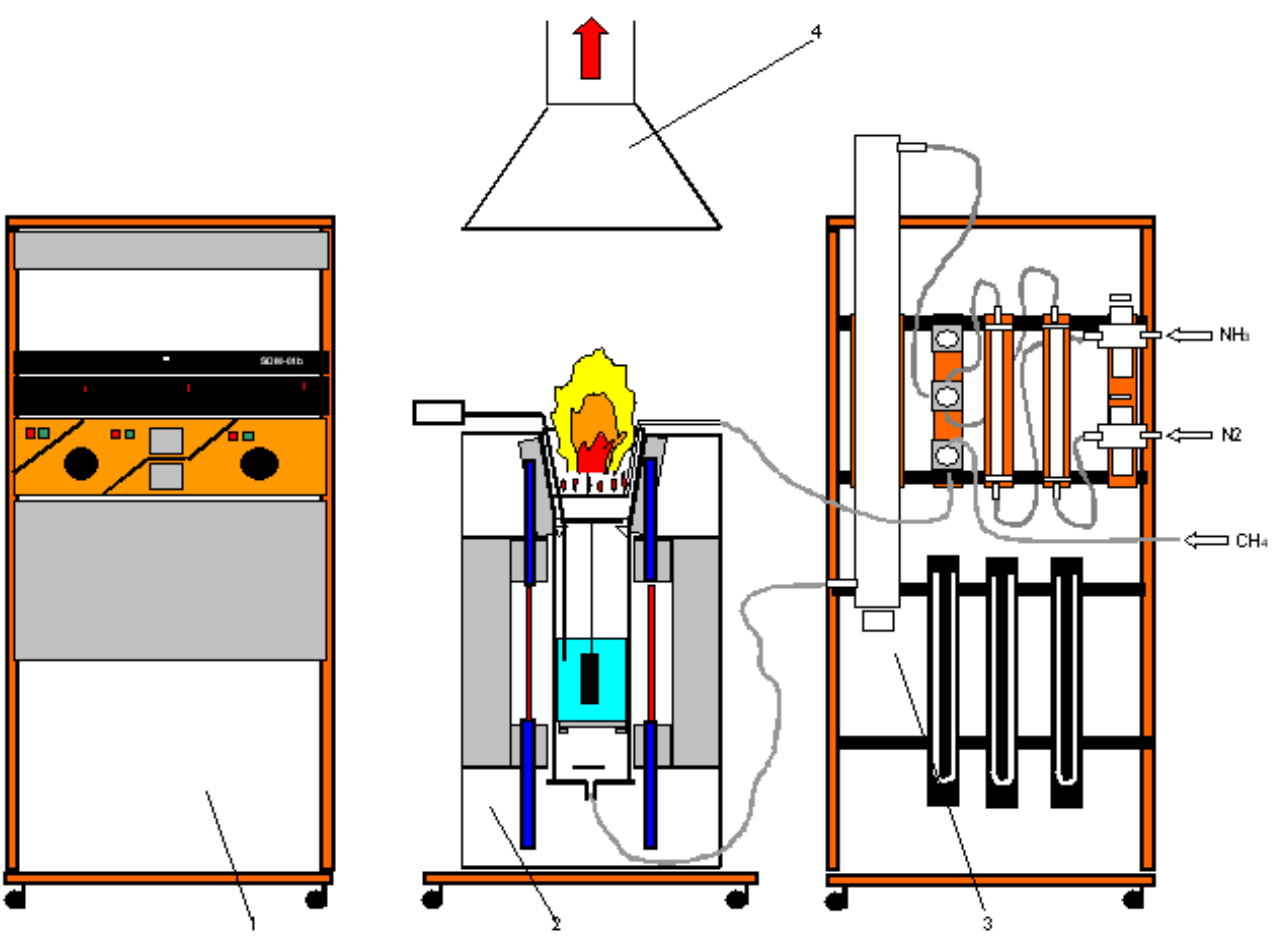

Fig. 2. Fluidized bed laboratory heat treatment furnace: 1 - power supply system and temperature control; 2 -fluidized bed oven; 3 - rack gas supply technological; 4 - hood to evacuate fumes

It is not necessary to remove samples from the fluidized bed; it is only necessary to avoid oxidation into the atmosphere or due to the residual moisture in the incoming gases. The oxidation was carried out at $570{ }^{\circ} \mathrm{C}$ for two hours of treatment. The duration was determined by previous tests and the temperature in the Fe-O diagram [4].

\section{Results and disscutions}

Investigations were conducted to determine the influence of thermochemical treatment conditions on the chemical composition, structure and properties, as follows:

- in section (layer) metallography;

- hardness over surface oxinitrocarburized layer;

- metallographic depth layer analysis.

Superficial hardness was analysed with the $5 \mathrm{~kg}$ hardness tester. Measurements were made on both surface hardness in each three randomly chosen points in the sections.
The paper aims at highlighting changes in the structure after application of thermochemical treatment cycle. With this respect, reference is the initial structure (blank) and the core structure of each sample.

For each sample of steel there is a clamp with nitrocarburated samples and oxinitrocarburated samples, with a minimum distance of $2 \mathrm{~mm}$ between samples. The clamps of the specimens are subjected to the process of preparation by grinding (abrasive stone 60 , polishing with sandpaper 100, 200, 300, $500,800,1000,1200)$ and polishing with diamond paste. Metallographic attack is made with $2 \%$ Nital. Metallographic analysis results represent the microstructure at 100x zoom for each sample.

The microstructures of the samples after $\mathrm{NC}+\mathrm{O}$ complex treatment are shown in Fig. 3...Fig. 18:

The largest depth of surface layer modified after (NC $+\mathrm{O}$ ) is for $\mathrm{NC}$ at $650{ }^{\circ} \mathrm{C}$ and $0.05-0.09 \mathrm{~mm}$ respectively. These are the layers that have the 
highest hardness, the high temperature allowing an intense nitrocarburisation (NC) process.

\section{Conclusions}

In this paper, the behaviour of low-carbon steel samples by nitrocarburizing treatment in a fluidized bed is aimed and then followed by a water-vapourcontrolled oxidation. Nitrocarburizing was carried out at $650{ }^{\circ} \mathrm{C}, 650$ to $570{ }^{\circ} \mathrm{C}, 570{ }^{\circ} \mathrm{C}$ and $540{ }^{\circ} \mathrm{C}$ and oxidation at $570{ }^{\circ} \mathrm{C}$. Basically it connects metallographic structure and hardness $\mathrm{HV}$ of the surface. It makes it with 5-10 loads from the core area.

As an expression of oxinitrocarburizing treatment it results in an elegant colour and surface appearance: black satin, matte. Final treatment after oxidation usually contains a space filler resulted (crevices) with a sealant (corrosion), usually oil.

In all the experimental samples there were observable alterations of the superficial layer (micrographs in section and surface hardness).

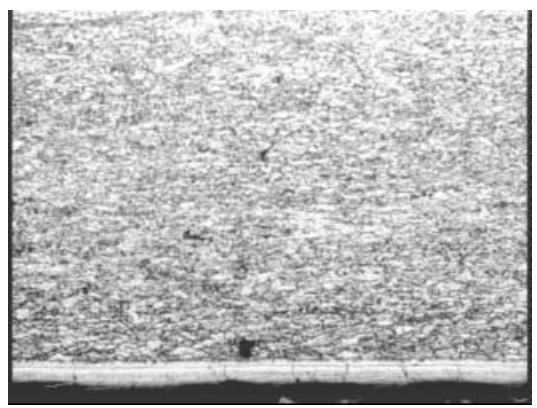

Fig. 3. Microstructure, sample 1: $\left(\mathrm{CN} 650{ }^{\circ} \mathrm{C} / 60\right.$ $\min +0,100 x)$

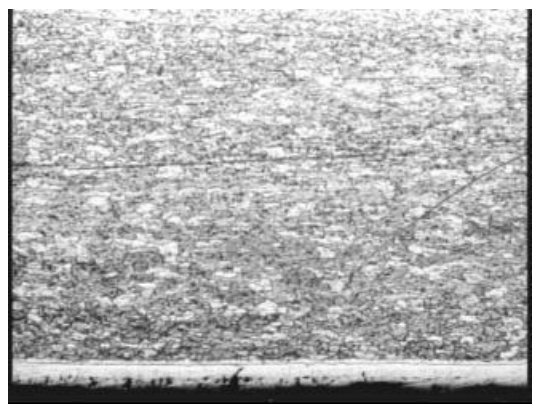

Fig. 4. Microstructure, sample $2:\left(\mathrm{CN} 650^{\circ} \mathrm{C} / 80\right.$ $\min +0,100 x)$

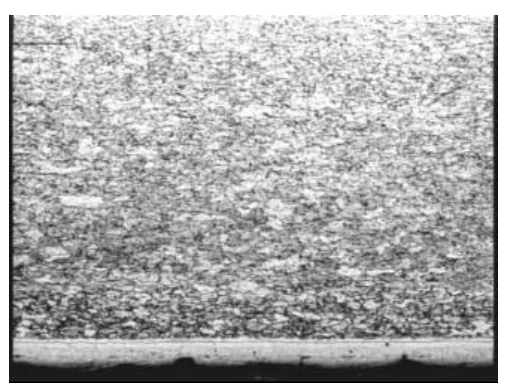

Fig. 5. Microstructure, sample 3: (CN650 $\left.{ }^{\circ} \mathrm{C} / 100 \min +0,100 x\right)$

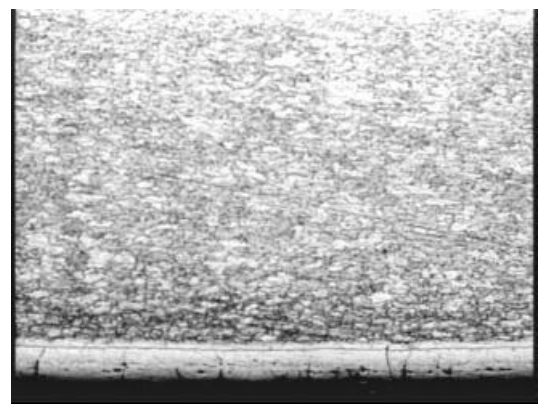

Fig. 6. Microstructure, sample 4: (CN650 $\left.{ }^{\circ} \mathrm{C} / 120 \min +0,100 x\right)$

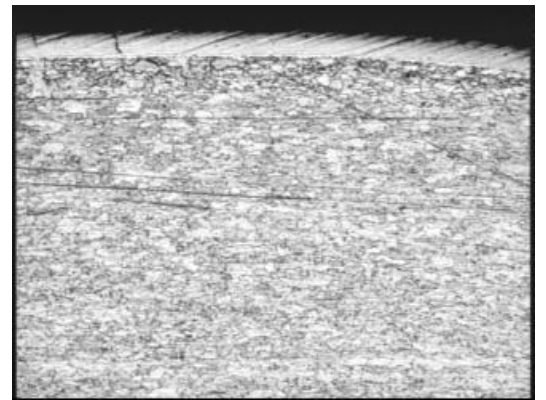

Fig. 7. Microstructure, sample 5: (CN650->570 ${ }^{\circ} \mathrm{C} / 60 \min +0,100 x$ )

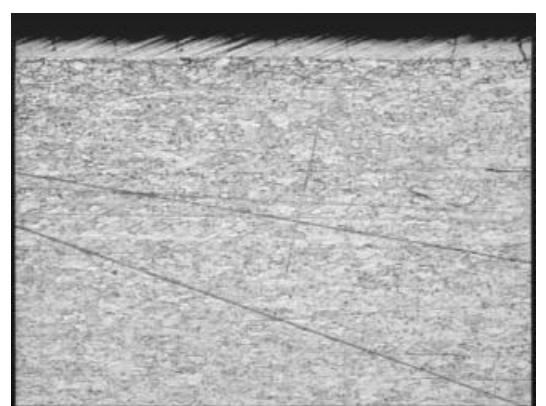

Fig. 8. Microstructure, sample 6: (CN650->570 $\left.{ }^{\circ} \mathrm{C} / 80 \min +O, 100 x\right)$ 


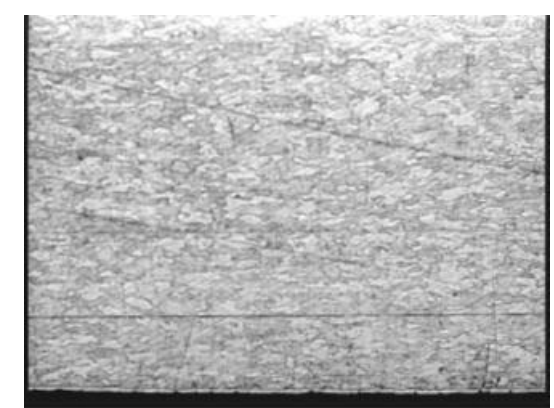

Fig. 9. Microstructure, sample 7: (CN650->570 ${ }^{\circ} \mathrm{C} / 100 \min +O, 100 x$ )

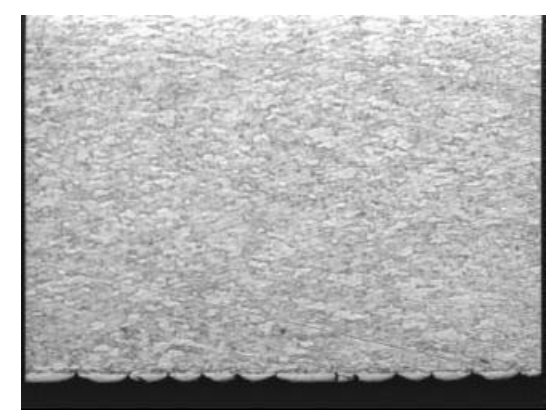

Fig. 10. Microstructure, sample 8: (CN650$\left.>570{ }^{\circ} \mathrm{C} / 120 \min +O, 100 x\right)$

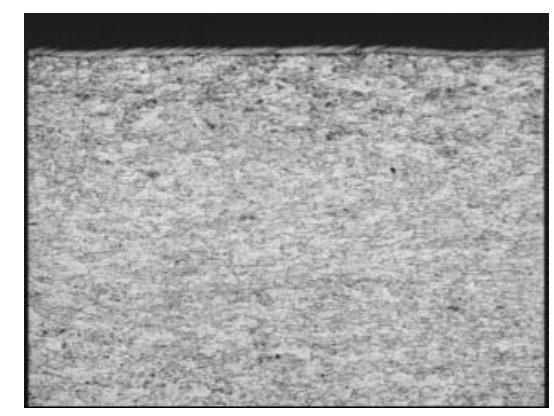

Fig. 11. Microstructure, sample 9: (CN570 $\left.{ }^{\circ} \mathrm{C} / 60 \min +O, 100 x\right)$

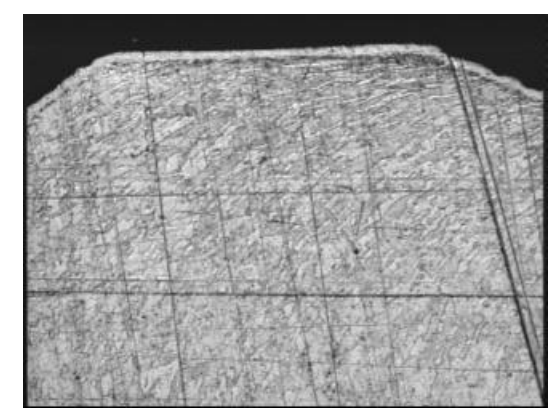

Fig. 12. Microstructure, sample 10: (CN570 $\left.{ }^{\circ} \mathrm{C} / 80 \min +O, 100 x\right)$

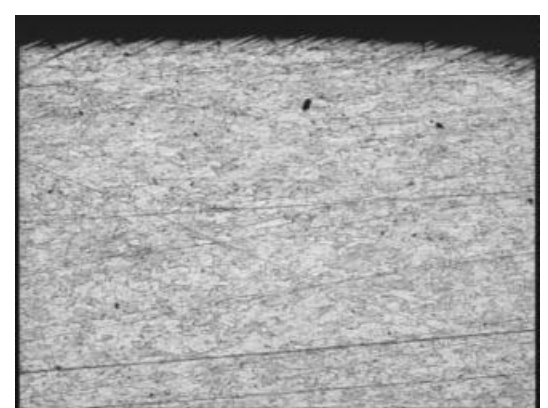

Fig. 13. Microstructure, sample 11: (CN570 $\left.{ }^{\circ} \mathrm{C} / 100 \min +O, 100 x\right)$

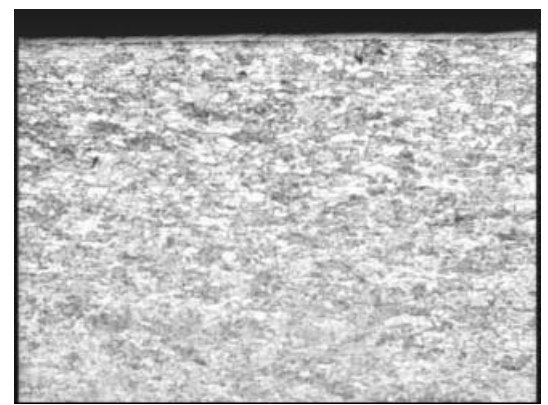

Fig. 14. Microstructure, sample 12: (CN570 ${ }^{\circ} \mathrm{C} / 120 \min +O, 100 x$ )

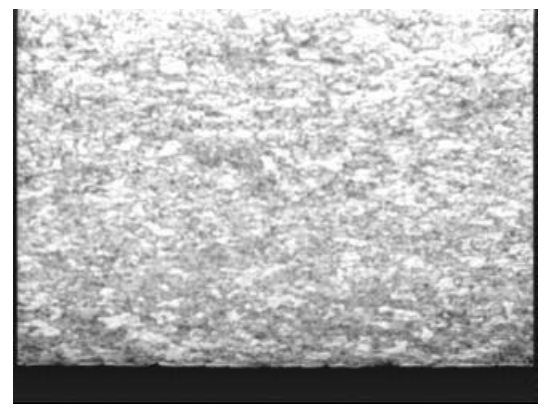

Fig. 15. Microstructure, sample 13: (CN540 $\left.{ }^{\circ} \mathrm{C} / 60 \min +O, 100 x\right)$

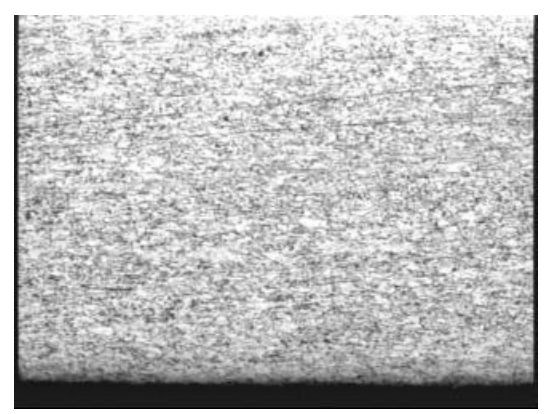

Fig. 16. Microstructure, sample 14: (CN540 ${ }^{\circ} \mathrm{C} / 80 \min +O, 100 x$ ) 


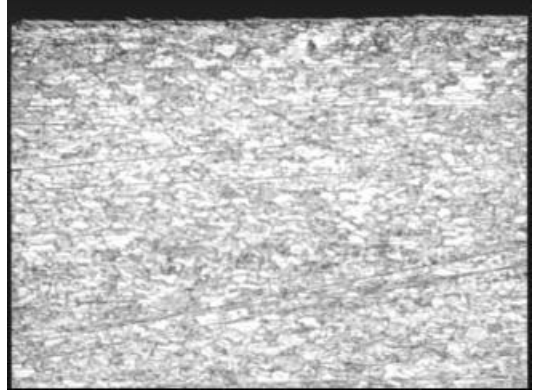

Fig. 17. Microstructure, sample 15: (CN540 $\left.{ }^{\circ} \mathrm{C} / 100 \min +O, 100 x\right)$

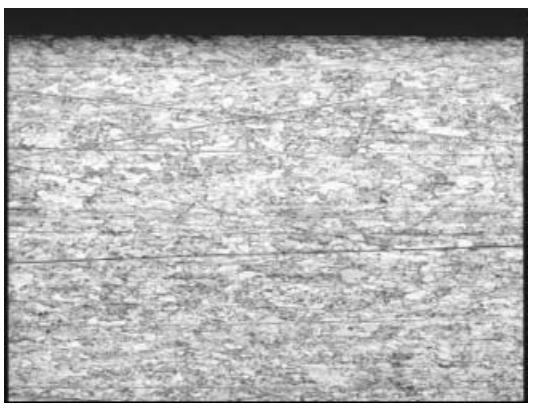

Fig. 18. Microstructure, sample 16: (CN540 $\left.{ }^{\circ} \mathrm{C} / 120 \min +O, 100 x\right)$

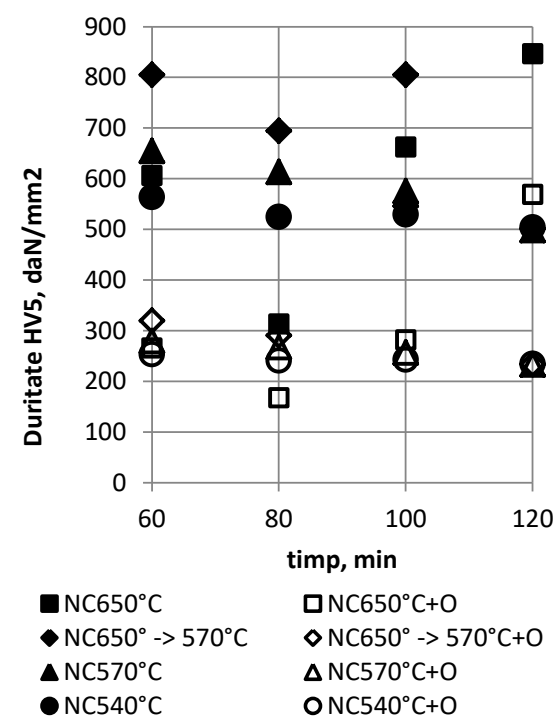

Fig. 19. Dispersion of hardness HV5 test over all samples after $\mathrm{CN}$ and after $\mathrm{CNO}$

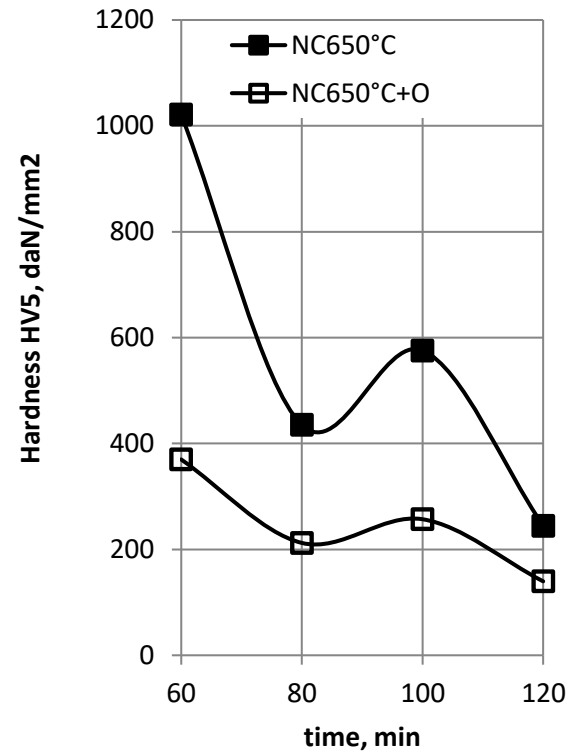

Fig. 20. Hardness after $\mathrm{CN}$ at $650^{\circ} \mathrm{C}$ and after O at $570{ }^{\circ} \mathrm{C}$

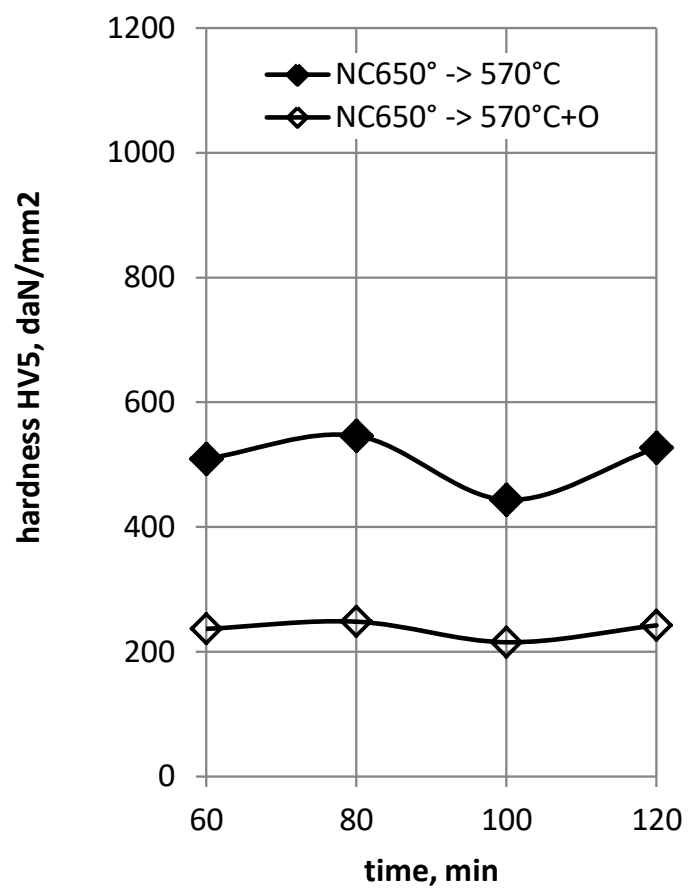

Fig. 21. Hardness after $\mathrm{CN}$ at $650^{\circ} \mathrm{C}->570{ }^{\circ} \mathrm{C}$ and after $\mathrm{O}$ at $570^{\circ} \mathrm{C}$ 


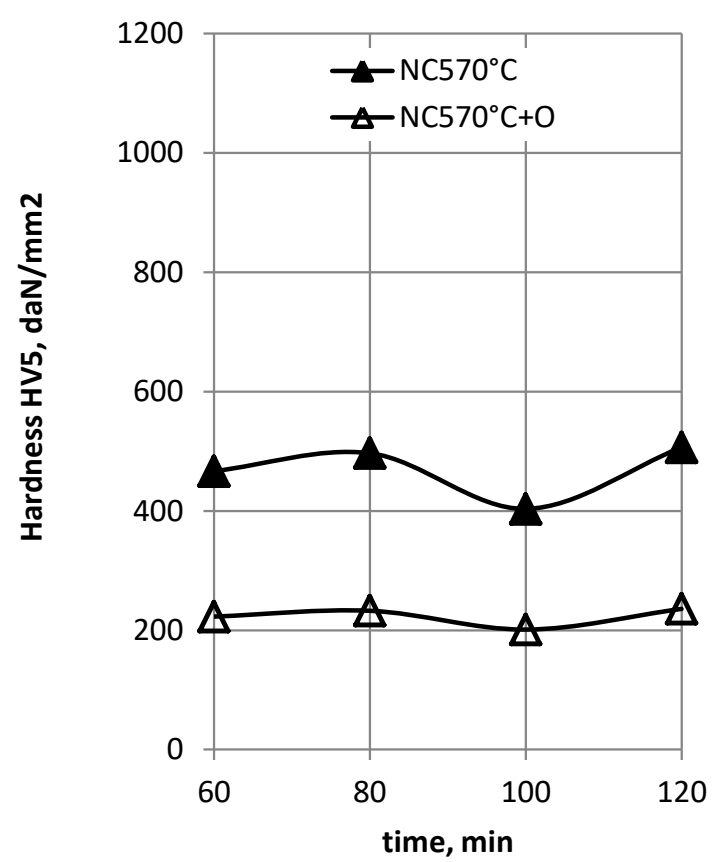

Fig. 22. Hardness after $\mathrm{CN}$ at $570{ }^{\circ} \mathrm{C}$ and after O at $570{ }^{\circ} \mathrm{C}$

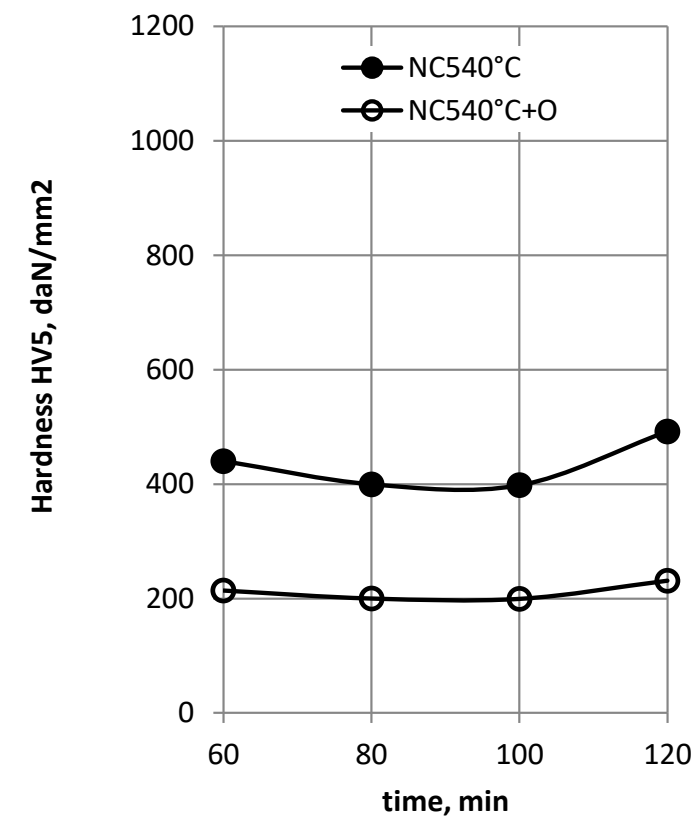

Fig. 23. Hardness after $\mathrm{CN}$ at $540^{\circ} \mathrm{C}$ and after O at $570{ }^{\circ} \mathrm{C}$

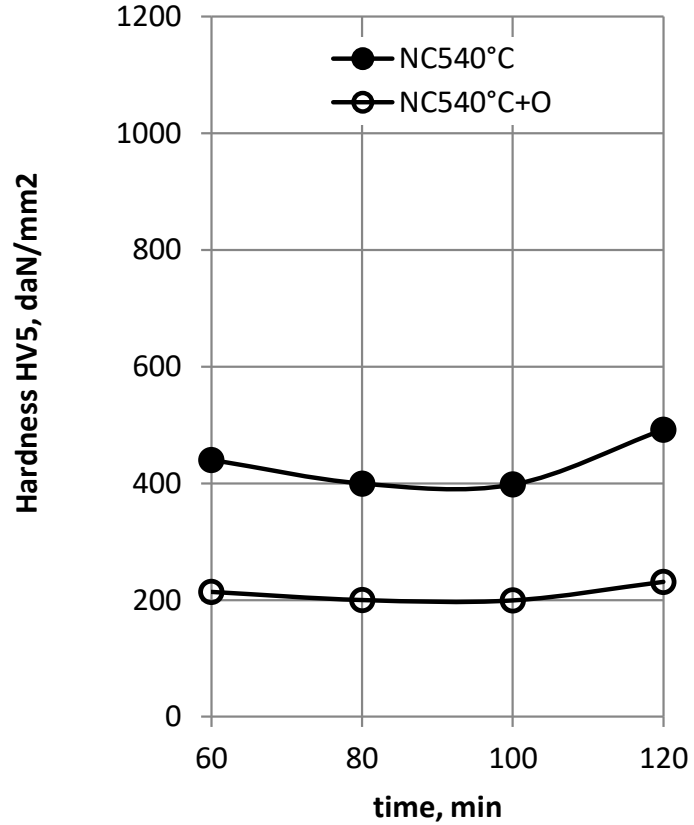

Fig. 24. Hardness after $\mathrm{CN}$ at $540^{\circ} \mathrm{C}$ and after O at $570{ }^{\circ} \mathrm{C}$

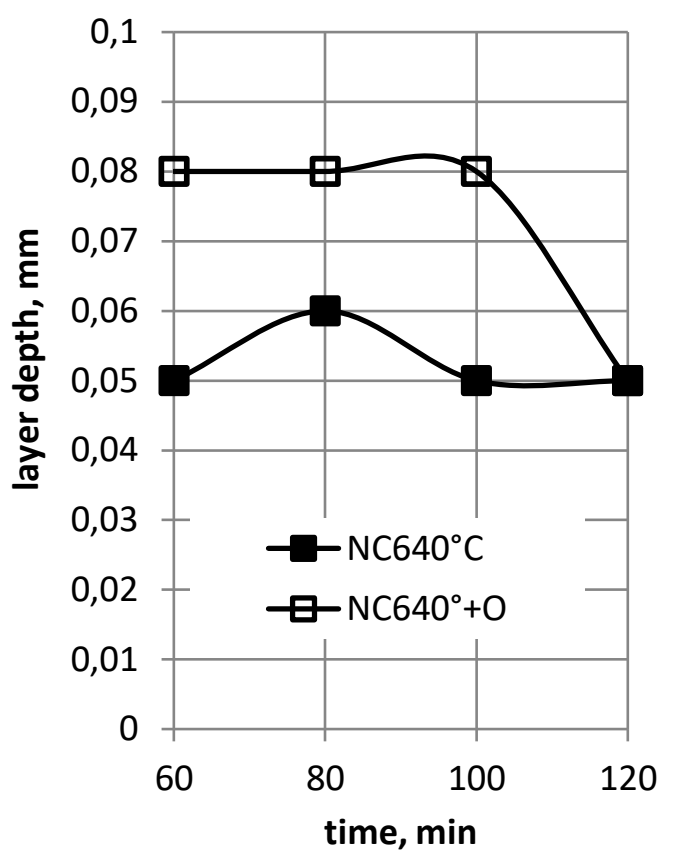

Fig. 25. Layer depth for $\mathrm{NC}$ at $640{ }^{\circ} \mathrm{C}$ with time and with/without $\mathrm{O}$ at $570{ }^{\circ} \mathrm{C}$ 


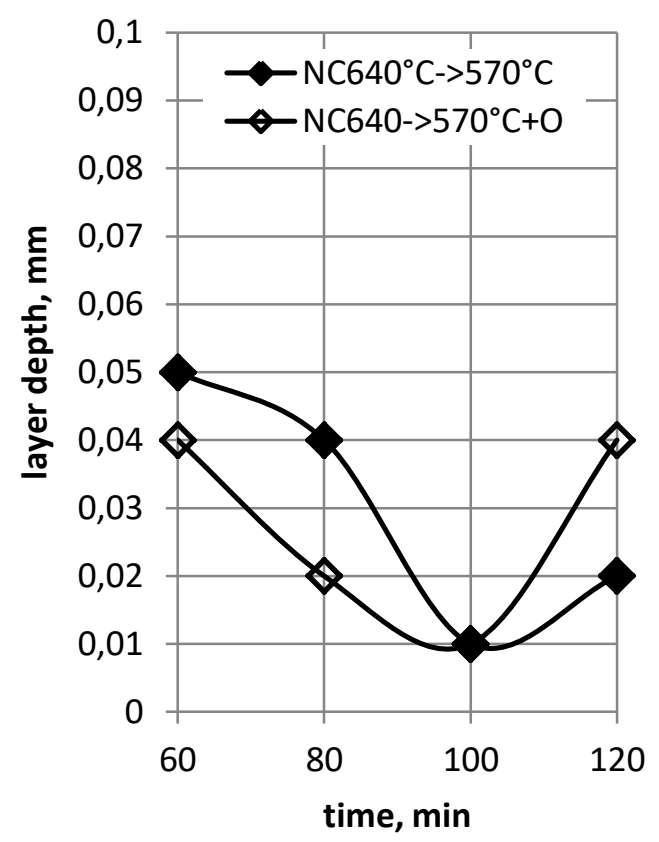

Fig. 26. Layer depth for $\mathrm{NC}$ at $640^{\circ} \mathrm{C}->570^{\circ} \mathrm{C}$ with time and with/without $\mathrm{O}$ at $570{ }^{\circ} \mathrm{C}$

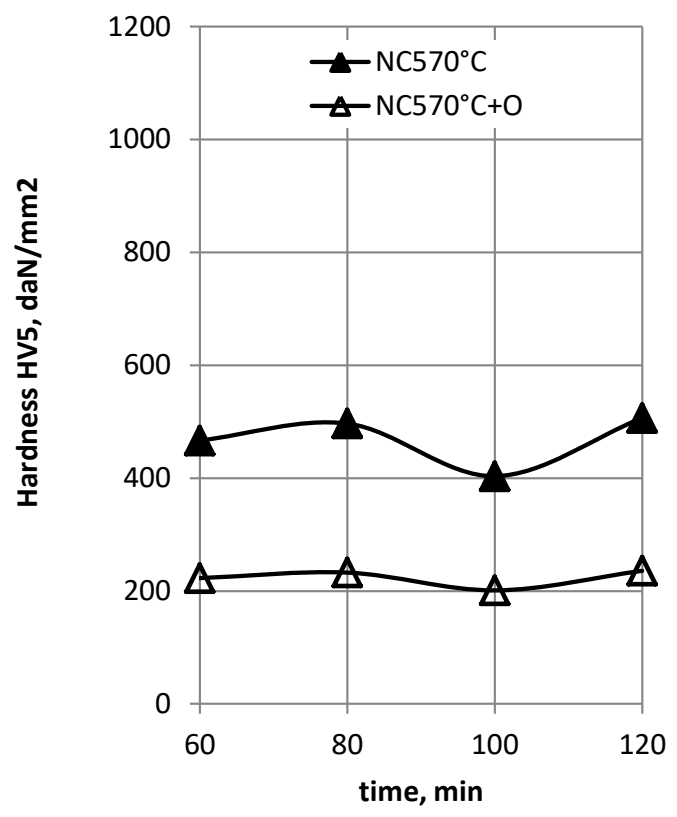

Fig. 27. Layer depth for $\mathrm{NC}$ at $570{ }^{\circ} \mathrm{C}$ with time and with/without $\mathrm{O}$ at $570{ }^{\circ} \mathrm{C}$

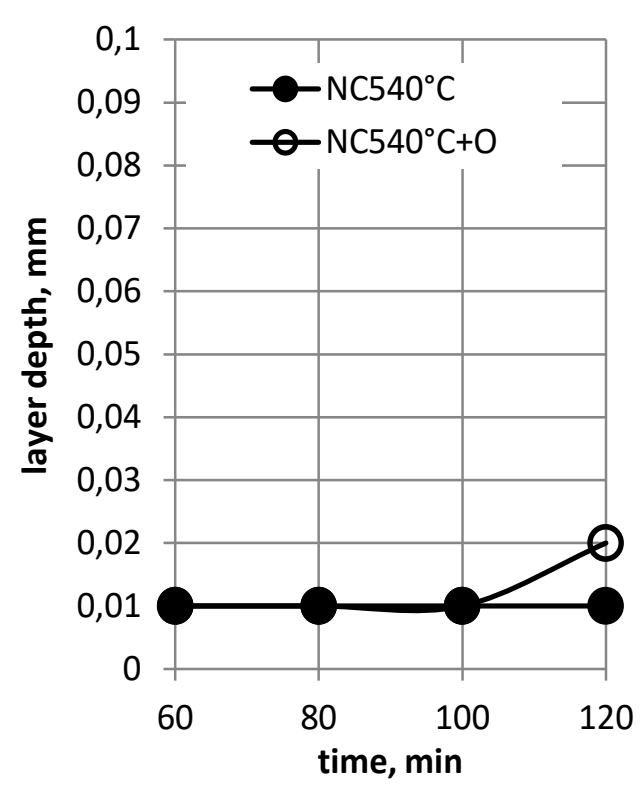

Fig. 28. Layer depth for $\mathrm{NC}$ at $540{ }^{\circ} \mathrm{C}$ with time and with/without $\mathrm{O}$ at $570{ }^{\circ} \mathrm{C}$

The layer with the highest depth and the most significantly modified properties was obtained for a temperature of $640{ }^{\circ} \mathrm{C}$, this being the highest treatment temperature (tab). By oxidizing at $570{ }^{\circ} \mathrm{C}$, the white-specific oxidation layer increases with temperature and residence time. The hardness of the losses is higher than that of the original material (65 $\mathrm{daN} / \mathrm{mm}^{2}$, HV5), indicating that the layer of inert material (crushed chamfered and sorted at 0.10-0.16 $\mathrm{mm}$ and fluidized with methane + ammonia and air mixture, and then with over-heated water vapour, there is an active environment for $\mathrm{NC}+\mathrm{O}$ processes. The lowest hardness is obtained at $540{ }^{\circ} \mathrm{C}$ being 500 $\mathrm{daN} / \mathrm{mm}^{2}$ (HV5) after the NC and decreasing to 250 $\mathrm{HV}$ (HV5) after $\mathrm{NC}+\mathrm{O}$.

The fluidized bed oxinitrocarburation process can be used to treat small parts made of stamping steels and which, after treatment, enables us to obtain better mechanical propensities and corrosion.

\section{References}

[1]. Pye D., Diffusion Surface Treatment Techniques: A Review, Meadville, PA: Industrial Heating, Pye Metallurgical Consulting Inc.

[2]. Cazacu N. et al., Oxydizing Influence over Surface Structures and Properties for A3k Steel, The Annals of "Dunarea de Jos" University of Galati, Fascicle IX, ISSN 1453-083X, no. 2, 2006. [3]. ***, ASM Handbook. Heat Treating, vol. 4, s.l.: ASM International, ISBN 0-87170-379-3, 1991.

[4]. Roland A., Oxicad(R)-NT en four a tapis. Traitement thermique, vol. 346, p. 37, 2003.

[5]. Mirjani M., Shafyei A., Ashrafizadeh F., Plasma and gaseous nitrocarburizing of C60W steel for tribological applications, Elsevier, vol. Vacuum, 83, 2009.

[6]. Mihăilă C., Procese termodinamice în sisteme gaz-solid şi aplicaţiile lor în industrie, Bucureşti: Editura Tehnică, 1983. 


\section{THE ANNALS OF “DUNAREA DE JOS” UNIVERSITY OF GALATI \\ FASCICLE IX. METALLURGY AND MATERIALS SCIENCE \\ №. 3 - 2018, ISSN 2668-4748; e-ISSN 2668-4756 \\ Article DOI: https://doi.org/10.35219/mms.2018.3.02}

[7]. Kunii D., Levenspiel O., Fluidization engineering, New York: John Wiley \& Sons Inc., 1969.

[8]. Baskakov A. P., Nagrev I., Ohlajdenie metallov v kipiasciem sloe, Moscova: Metalurghia, 1974

[9]. Cazacu N., Cercetări privind tehnologia de tratament termic in strat fluidizat pentru semifabricate siderurgice şi piese, (doctoral thesis), Galaţi: Universitatea "Dunărea de Jos”, 2000.

[10]. Cazacu N. et al., Carburarea în strat fluidizat, Galaţi: Editura Fundaţiei Universitare „Dunărea de Jos” Galaţi, 2001.

[11]. Samoila C. Drugă, Stan I., Cuptoare şi instalaţii de incălzire, Bucureşti: Editura Didactică şi Pedagogică, 1983.

[12]. Samoila C., Ionescu M. S., Drugă L., Tehnologii şi utilaje moderne de incălzire, București: Editura Tehnică, 1986.

[13]. Vermeşan G., Tratamente termice, Îndrumător, Editura Dacia: Cluj Napoca, 1987. 